\title{
Country governance, tourism and environment quality: An emerging economy perspective
}

\author{
Sadaf Akram ${ }^{a *}$, Nayyer Sultana ${ }^{b}$, Tanzilla Sultana $^{c}$, Mamoona Majeed $^{\mathrm{d}}$ and Rufia Saeed $^{\mathrm{a}}$
}

${ }^{a}$ Department of Commerce, Government College Women University, Faisalabad, Pakistan

${ }^{b}$ Department of Public Administration, Government College Women University, Faisalabad, Pakistan

${ }^{c}$ Allied Bank Limited, Faisalabad, Pakistan

${ }^{d}$ Finance Manager, Elite Falcon Management Consultants, Dubai, United Arab Emirates

\section{H R O N I C L E}

Article history:

Received: December 12, 2020

Received in revised format:

December 292020

Accepted: February 17, 2021

Available online:

February 17, 2021

Keywords:

Tourism

Country Governance

Rule of Law

Control of Corruption

Political Stability Government Ef-

fectiveness

Environmental Quality

\section{A B S T R A C T}

The objective of the study has two folds: first, the study analyzes the role of country governance in tourism. Second, the study investigates the impact of tourism on the environmental quality. For this purpose, the data from 1997 to 2018 are collected from the World Bank and Global Economy. Augmented Dickey Fuller (ADF) test and ordinary least square regression models are used to analyze the impact. The study finds positive impact of rule of law, control of corruption, political stability and government effectiveness on tourism. The study also finds a negative relation between tourism and environmental quality of Pakistan. The study recommends the tourism destination planners to continuously monitor their country and to work with the government towards stability and protection and safety of tourists and for the general public. The rules to control corruption must also be implemented in a blanket form. The study also recommends the researchers to promote research on the relationship between country governance and tourism. Overall, the evidence of the study provides innovative information regarding the impact of country governance on tourism and tourism on environmental quality, which political leaders, tourist analysts and policymakers can use to shape policies in order to promote the tourist industries.

(C) 2021 by the authors; licensee Growing Science, Canada

\section{Introduction}

At the end of the twentieth century, country governance has become the hottest topic in various spheres, government, society at large and academia; numerous insinuations to the subject, both in conversation and writing, nothing has become unusual. Allusions to the country governance - at territorial, multiple or local levels, or in terms of action of government in a specific field, and tourism is no exception - currently proliferate in day-to-day life. Tourism is a process and act of spending time from outside the home in pursuit of relaxation, refreshment and pleasure. Tourism is considered as a product of recent communal provisions started in the seventeenth century in Europe. One can safely define country governance as a concept that is more stated that unspoken. Numerous definitions of country governance are available; some of these are described in the study. Country governance is described as a process of conducting public affairs and managing public resources by public institutions or government of a country (Duran, 2013). Country governance contains institution and tradition and authorities are exercised with the help of these institutions and traditions. It consists of a process through which the government is elected, selected, replaced or overseen. It is the capacity of a country's government to formulate and effectively accomplish good public policies. Country governance is described as how civilization oversees and uses political authority in order to effectively manage resources for social and economic development; the process of considering the role of authorities of public in order to establish an environment in which government operates and in defining how to distribute the benefits; it also describes the nature of the association between public at large and government (Organization for Economic Cooperation and Development, 1995). * Corresponding author.

E-mail address: sadafakramgcwuf@gmail.com (S. Akram) 
Country governance is a process of decision making and a process of implementing those decisions (United Nation Economic and Social Commission for Asia and Pacific, 2006). Country governance describes the behaviors, processes and norms used to exercise the powers at the level of Europe, specifically from the viewpoint of coherence, participation, effectiveness, accountability and openness (Commission of the European Communities, 2001). Country governance comprises various processes, mechanisms, systems, institutions and relationships through which the public eloquently identify their interests, identify their obligations, reconcile their differences and exercise their lawful rights (United Nations Development Programs, 1997). Based on the above cited concepts of country governance, the study provides the following definitions with the aim of above identification in order to coordinate and undertake an evolution towards a new form of country governance in the tourism sector. Country governance is defined as a government's practice that is measurable, that aims to effectively and efficiently directs the tourism industry at the various governments' levels through the methods of collaboration, cooperation and coordination that are transparent, efficient and subject to accountability that helps in achieving goals of collective interest shared by tourists (Duran, 2013). A country's condition whose government is controlled by political parties or where fundamental prerequisites for social order maintenance and control are not stable and occasionally disturbed is said to be political instability (Sonmez 1998; Munnell \& Cook 1990). Various measurements of political instability are identified in the context of international tourism like civil and international wars, riots, social and political unrest coups and strikes (Hall \& O’Sullivan 1996). The association between tourism and politics is not basically concerned with electing political parties. Tourism policy is not a facet of politics and politics does not lengthen any effect on tourism policy. The main determination of tourism policy is to assimilate the political, intellectual, economic and cultural benefit of tourism with countries, destinations and people in order to improve quality of life at large and provide a base for prosperity and peace. Tourism is not only considered as politics' continuation but it is considered as an important part of the political economy of the world. Shortly, tourism is a tool that is used for economics as well as political means (Paskaleva-Shapira, 2007). This tourism tool consists of rule of law principles. The principle of rule of law should be done with the discernment of justice, and this rule of law is strongly associated with the human rights issue. The rule of law is a legal tool consisting of legal rules which are entirely related to the activities concerning tourism (Phakdisoth \& Kim, 2007). Although, the research on the rules related to tourism is not fully explored yet. A country's government who follows the principle of rule of law is said to be an effective government.

The government effectiveness describes the perceptions regarding the quality of public as well as civil services, the extent of its independence from the pressures of political entities, the quality of formulation and implementation of policies and the government's credibility and commitments to these policies. Challenge of government effectiveness in the development of tourism industry is to determine an appropriate level of their effectiveness in order to effectively control the business as well as individual activities. Such discussion has been provocative in existing debate (Hall, 2006; Hoxha, 2010; Kubickova, 2016). The primary concern of an effective government is to provide the services beneficial for the general public and which markets cannot provide, defense from outside threats and enforcement of law and order (Micheal, 2001). Corruption is also a threat that must be controlled by an effective government. The control of corruption represents the degree of opinions to which public power is used for personal benefits including grand and petty types of corruption as well as state seizure. The effect of corruption on tourism in the tourism field is not much cleared. Poprawe (2015) examined the impact of corruption on tourism and finds that a decrease in the corruption levels leads to enhance the tourists' inflows. She finds a negative impact of corruption on tourism. Similarly, Das and DiRienzo (2010) and Saha and Yap (2015) also prove that corruption has a negative impact on tourism. Alternatively, Lv and Xu (2017) found a positive impact of corruption on tourism demand. The regulatory quality captures the ability of a country's government regarding formulation and implementation of sound regulations and policies that license and promote the development of the private sector. Voice and accountability index represents the degree of opinions to which the residents of a nation participate in electing the government, as well as freedom of association and expression, human and political rights, civil liberties and free press or media.

Latest empirical studies describe the importance of infrastructure of country governance and demonstrate that it has an intense impact on the tourism sector (Erkuş-Ozturk \& Eraydin, 2010; Goymen, 2000; Beaumont \& Dredge, 2010). The tourism sector in the world has recognized itself as an industry of strategic importance in the domestic economy. The tourism sector of an economy positively contributes to economic progress as it plays a positive role in reducing the budget deficit. Regardless of its importance, the tourism industry is one of the largest contributors to the GHG emissions. According to a report, world's tourism and the sector of air transport is the fourth largest emitter. Researchers also revealed a positive impact of the tourism sector in deteriorating the environmental quality. Researchers believed that the tourist activities require the consumption of more energy at different stages i.e., at the stage of transport, catering, and accommodation which resultantly deteriorate the environmental quality by increasing the level of GHG emissions in the atmosphere. Present study, therefore, proposes the significant relationship between country governance, tourism and environmental quality.

Most of the related studies of governance and tourism mainly focus on two or three dimensions of governance, e.g., corruption, government effectiveness and political instability (Bramwell \& Lane, 2011; Buckley, 2012; Zapata \& Hall, 2012; Presenza, Del Chiappa \& Sheehan, 2013). However, country governance should not be restricted to only two or three dimensions. The study, therefore, contributes to the existing knowledge by identifying six dimensions of country governance namely; rule of law, regulatory quality, control of corruption, political stability, voice and accountability and government effectiveness to analyze the role of country governance on tourism. Meanwhile, the study also investigates the impact of Tourism on environmental quality 
The rest portion of the study classified as: section two provides the review of previous literature and construction of hypotheses, third section presents the data and methodologies, section four consists of empirical results and section five provides the discussion on the findings and also concludes the research.

\section{Literature Review and Hypotheses Development}

This section explains the review of the related literature and construction of the hypotheses:

\subsection{Tourism and Rule of Law}

Steyn and Vuuren (2016) analyzed the relationship between good governance and tourism by using rule of law as a proxy of good governance on the sample of 158 countries. The findings showed a positive relationship between tourism and rule of law. They concluded that tourists showed more concern towards countries with better rule of law. Similarly, Maniatis (2016) analyzed the impact of rule of law on tourism and found a positive impact of rule of law on tourism. Tsai et al. (2012) investigated the relation between tourism and the rule of law by using the sample of secular rational adjusted countries and found a direct relationship between tourism and rule of law.

$\boldsymbol{H}_{1:}$ There is a positive impact of rule of law on tourism.

\subsection{Tourism and Regulatory Quality}

Steyn and Vuuren (2016) analyze the impact of good governance on tourism. Regulatory quality was used as a proxy of good governance. Their results showed a negative relationship between regulatory quality and tourism. Similarly, Maniatis (2016) also found a negative impact of regulatory quality on tourism. Alternatively, Tsai et al. (2012) found an insignificant impact of regulatory quality on tourism.

$\boldsymbol{H}_{2:}$ Regulatory quality has a negative impact on tourism.

\subsection{Tourism and Control of Corruption}

Gallego et al. (2016) investigated the relationship between tourism and corruption using a sample of 171 countries for the period of 1995 to 2013. Demand model of aggregated tourism at country level and disaggregation model of tourism appearance was used to analyze the results. The outcomes of the aggregated model showed no relation between corruption and tourism while the disaggregated model showed an inverse relationship between corruption and tourism in the country of destination. Tsai et al. (2012) observed the relation between tourism and the control of corruption and found a negative association between tourism and corruption. Steyn and Vuuren (2016) also observed a negative impact of corruption on tourism. Das and Dirienzo (2010) investigated the interaction between tourism competitiveness and corruption using a sample of 119 countries. They found a negative relationship between tourism and corruption. Against the above studies, Ekine (2018) studied the impact of corruption on tourism using the sample of 194 countries for the period of 1996 to 2016. He found a significant positive impact of corruption on tourism. Moreover, corruption was found to be strongly significant in democratic countries as compared to non-democratic countries.

\section{H3: There is a positive relationship between control of corruption and tourism.}

\subsection{Tourism and Political Stability}

Ingram et al. (2013) analyzed the relationship between political instability and consumer behavior tourism using quantitative and cross-sectional approaches and advancing the case study by comparing the attitude of offenders who had and had not get a journey towards Thailand. The findings demonstrated a negative impact of political instability on tourism. There was a temporary political instability towards the tourism industry of Thailand. Tsai et al. (2012) found a positive association between political stability and tourism. Steyn and Vuuren (2016) examined the relationship between good governance and tourism by using political stability as a proxy of good governance and found a positive interaction between political stability and tourism.

\section{H4: There is positive association between political stability and tourism.}

\subsection{Tourism and Voice and Accountability}

Steyn and Vuuren (2016) analyzed the effect of good governance on tourism. A proxy of voice and accountability was used as a measure of good governance. A sample of 158 countries was analyzed. A negative impact of voice and accountability was found in the sample countries. They concluded that good governance significantly determined tourism. Fuentes (2013) examined the relationship between country governance and tourism. He found a negative association between voice and accountability and tourism. 
$\boldsymbol{H}_{5}$ : Voice and accountability has a negative impact on tourism.

\subsection{Tourism and Government Effectiveness}

Kubickova (2016) analyzed the role of government in the competitiveness of tourism in the central region of the United State of America using panel data analysis. He found a significant role of government in the tourism industry. Tsai et al. (2012) found a significant interaction between tourism and the effectiveness of government. Fuentes (2013) examined the impact of effective governance on tourism and found a positive impact of effective governance on tourism. Steyn and Vuuren (2016) analyzed the relationship between good governance and tourism using government efficiency as a proxy of good governance. They also found a positive relationship between government effectiveness and tourism.

$\boldsymbol{H}_{6}:$ There is a positive impact of government effectiveness on tourism.

\subsection{Tourism and Environmental Quality}

Paramati et al. (2017) examined the relationship between tourism and environmental quality in the context of European Nation and found a negative link between these variables. Danish and Wang (2018) also explored the dynamic impact of tourism and economic growth on environmental quality of South Africa and found that the environmental quality of the selected country is significantly influenced by tourism and economic growth. Gupta and Dutta (2018) also revealed the similar findings for the case of Asian economies.

\section{$\boldsymbol{H}_{7}$ : There is a negative impact of tourism on environmental quality.}

\section{Methodology}

\subsection{Data and Sources}

The objective of the present study has two folds: First, the study analyzes the role of country governance on tourism. Second, the study investigates the impact of tourism on environmental quality. For this purpose, the study collected the data of Pakistan for the period of 1997-2018 from two different sources i.e., World bank, and global economy. Study applies Augmented Dickey Fuller (ADF) test to test the stationarity properties of the variables and ordinary least square regression model is used to analyze the impact of variables. The study used two different proxies of tourism, that is tourism receipts ( $\mathrm{t}$-receipts), and tourism arrivals ( $\mathrm{t}$ arrivals). Per capita carbon emissions are used to measure the environmental quality Six governance indicators developed by Kaufmann, Kraay and Lobaton (2005) are used to measure country governance, used as an independent variable of the study in model 1 . These indicators include: i) rule of law, ii) regulatory quality, iii) control of corruption, iv) political stability, v) voice and accountability and vi) government effectiveness. These governance indices range from -2.5 to 2.5. The higher value of these indices represents better governance. Study used the following econometric models to accomplish the proposed objective of the study.

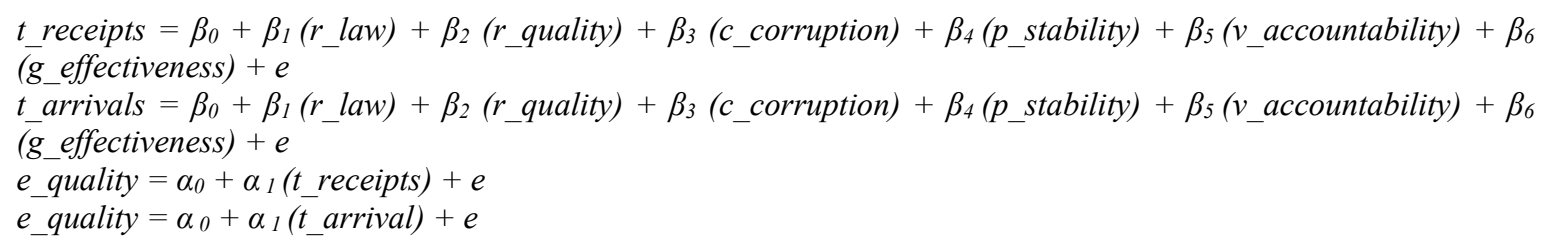

where; t_receipts: tourists' receipts, t_arrivals: tourism arrivals, $r \_l a w$ : rule of law, r_quality: regulatory quality, c_corruption: control of corruption, p_stability: political stability, v_accountability: voice and accountability: g_effectiveness: government effectiveness, e_quality is environmental quality, $\alpha_{0}$, and $\beta_{0}$ are the constants, $\beta_{1----} \beta_{6}$ and $\alpha_{1}$ are the slope coefficients and e represents the error term. The description of the variables, along with their operational definition are presented in the next section.

\subsection{Variables Description}

\subsubsection{Tourism}

It is defined as a process and act of spending time from outside the home in pursuit of relaxation, refreshment and pleasure. Tourism is considered as a product of recent communal provisions started in the seventeenth century in Europe. Two proxies are used to measure this variable; international tourism receipts (treceipts) as a percentage of total exports and international tourism number of arrivals ( $t$ _arrivals). The data of tourism variables are extracted from the World Bank Website. 


\subsubsection{Rule of Law (r_law)}

The rule of law index represents the degree of opinions to which people have confidence in and abide by the society's rules, and particularly the property rights, the courts, contract enforcement quality, contract enforcement quality and likelihood of violence and crime. The mean value of index of rule of law for the study period is 0.04 points ranging from -0.23 points (2009) to 0.58 points (2000) (World Bank).

\subsubsection{Regulatory Quality (r_quality)}

The regulatory quality index captures the ability of a country's government regarding formulation and implementation of sound regulations and policies that license and promote the development of the private sector. The average value of the index of regulatory quality for the study period is 0.23 points with a maximum of 0.49 points in 2000 and minimum of 0.06 points in 1996 (World Bank).

\subsubsection{Control of Corruption (c_corruption)}

The control of corruption index represents the degree of opinions to which public power is used for personal benefits including grand and petty types of corruption as well as state seizure. The mean value of index of rule of law for the study period is 0.32 points ranging from -0.49 points (2015) to -0.07 points (1998) (World Bank).

\subsubsection{Political Stability (p_stability)}

Political stability index represents the likelihood of threats of violence to government or the changes in government including social unrest, terrorism and armed conflicts. The average value of the index of regulatory quality for the study period is -0.70 points with maximum of 0.64 points in 1998 and minimum of -1.44 points in 2010 (World Bank).

\subsubsection{Voice and Accountability (v_accountability)}

Voice and accountability index represents the degree of opinions to which the residents of a nation participate in electing the government, as well as freedom of association and expression, human and political rights, civil liberties and free press / media. The mean value of index of rule of law for the study period is -0.32 points ranging from -1.05 points (2017) to 0.47 points (2000) (World Bank).

\subsubsection{Government Effectiveness ( $g$ _effectiveness)}

The government effectiveness describes the perceptions regarding the quality of public as well as civil services, the extent of its independence from the pressures of political entities, the quality of formulation and implementation of policies and the government's credibility and commitments to these policies. The average value of the index of regulatory quality for the study period is 0.29 points with maximum of 0.45 points in 2006 and minimum of 0.09 points in 1998 (World Bank).

\subsubsection{Environmental Quality (e_quality)}

Environmental quality refers to the quality of the atmosphere. Environmental quality usually deteriorated due to increase in per-capita emissions. Present study measures the environmental quality with per capita $\mathrm{CO}_{2}$ emissions.

\section{Empirical Results}

\subsection{Unit Root Test}

The most commonly used Augmented Dickey Fuller (ADF) unit root test is applied in Table 1 for each variable to check stationary in the time series data. The Table shows that all the variables used in the study achieved stationary at level.

\subsection{Descriptive Statistics}

Table 2 shows the descriptive statistics for all the variables used to analyze the impact of country governance on tourism. The table represents that the mean value of tourists' arrivals is 0.88 ranging from 0.55 to 1.34 . The average value of tourists' receipts is 6.69 with the maximum and minimum value of 7.99 and 5.54 respectively. The mean value of rule of law is 0.11 ranging from -0.23 to 0.58 . The average value of regulatory quality is 0.23 with the maximum and minimum value of 0.49 and 0.06 respectively. The mean value of control of corruption is -0.29 ranging from -0.49 to -0.07 . The average value of political stability is -0.53 with the maximum and minimum value of -1.44 and 0.64 respectively. The mean value of voice and accountability is -0.23 ranging from -1.05 to 0.47 . The average value of government effectiveness is 0.27 with the maximum and minimum value of 0.45 and 0.26 respectively. The mean value of environmental quality is 0.5073 ranging from 0.98743 to 0.4736 . Tourists' arrivals, tourists' receipts, rule of law, regulatory quality, control of corruption, political stability, voice and accountability, government effectiveness and environmental quality show $+24 \%,+81 \%,+31 \%,+13 \%,+12 \%,+79 \%$, $+53 \%,+10 \%$, and $+4 \%$ variations respectively. 
Table 1

Augmented Dickey Fuller Test

\begin{tabular}{|c|c|c|c|c|c|c|}
\hline \multirow{3}{*}{ Variable } & \multicolumn{3}{|c|}{ At Level } & \multicolumn{3}{|c|}{ First Difference } \\
\hline & \multirow{2}{*}{$\begin{array}{c}\text { ADF Statistics } \\
-3.6788^{* *}\end{array}$} & \multicolumn{2}{|c|}{ Critical Value } & \multirow{2}{*}{$\begin{array}{c}\text { ADF Statistics } \\
-4.3212^{* * * *}\end{array}$} & \multicolumn{2}{|c|}{ Critical Value } \\
\hline & & $1 \%$ Level & -3.7880 & & $1 \%$ Level & -3.8085 \\
\hline \multirow{2}{*}{ t_receipts } & $(0.0426)$ & $5 \%$ Level & -3.0123 & $(0.0034)$ & $5 \%$ Level & -3.0206 \\
\hline & & $10 \%$ Level & -2.6461 & & $10 \%$ Level & -2.6504 \\
\hline \multirow{3}{*}{ t_arrivals } & $-3.7338 * *$ & $1 \%$ Level & -3.7880 & $-3.6319^{* * *}$ & $1 \%$ Level & -3.8085 \\
\hline & $(0.0299)$ & $5 \%$ Level & -3.0123 & $(0.0145)$ & $5 \%$ Level & -3.0206 \\
\hline & & $10 \%$ Level & -2.6461 & & $10 \%$ Level & -2.6504 \\
\hline \multirow{3}{*}{ r_law } & $-2.6700 *$ & $1 \%$ Level & -3.8085 & $-5.4493^{* * *}$ & $1 \%$ Level & -3.8573 \\
\hline & $(0.0630)$ & $5 \%$ Level & -3.0206 & $(0.0004)$ & $5 \%$ Level & -3.0403 \\
\hline & & $10 \%$ Level & -2.6504 & & $10 \%$ Level & -2.6605 \\
\hline \multirow{3}{*}{ r_quality } & $-3.5721^{* * *}$ & $1 \%$ Level & -3.7880 & $-3.5806^{* * * *}$ & $1 \%$ Level & -3.8867 \\
\hline & $(0.0159)$ & $5 \%$ Level & -3.0123 & $(0.0183)$ & $5 \%$ Level & -3.0521 \\
\hline & & $10 \%$ Level & -2.6461 & & $10 \%$ Level & -2.6665 \\
\hline \multirow{3}{*}{ c_corruption } & $-3.8103 * * *$ & $1 \%$ Level & -3.7880 & $-4.8216^{* * * *}$ & $1 \%$ Level & -3.8085 \\
\hline & $(0.0036)$ & $5 \%$ Level & -3.0123 & $(0.0011)$ & $5 \%$ Level & -3.0206 \\
\hline & & $10 \%$ Level & -2.6461 & & $10 \%$ Level & -2.6504 \\
\hline \multirow{3}{*}{ p_stability } & $-2.2697^{*}$ & $1 \%$ Level & -3.7880 & $-3.0979^{* * *}$ & $1 \%$ Level & -3.8085 \\
\hline & $(0.0623)$ & $5 \%$ Level & -3.0123 & $(0.0130)$ & $5 \%$ Level & -3.0206 \\
\hline & & $10 \%$ Level & -2.6461 & & $10 \%$ Level & -2.6504 \\
\hline \multirow{3}{*}{ v_accountability } & $-4.3370 * * *$ & $1 \%$ Level & -3.7880 & $-3.7654^{* * * *}$ & $1 \%$ Level & -3.8085 \\
\hline & $(0.0004)$ & $5 \%$ Level & -3.0123 & $(0.0110)$ & $5 \%$ Level & -3.0206 \\
\hline & & $10 \%$ Level & -2.6461 & & $10 \%$ Level & -2.6504 \\
\hline \multirow{3}{*}{ g_effectiveness } & $-2.5465^{* *}$ & $1 \%$ Level & -3.7880 & $-4.1998^{* * *}$ & $1 \%$ Level & -3.8085 \\
\hline & $(0.0491)$ & $5 \%$ Level & -3.0123 & $(0.0043)$ & $5 \%$ Level & -3.0206 \\
\hline & & $10 \%$ Level & -2.6461 & & $10 \%$ Level & -2.6504 \\
\hline \multirow{3}{*}{ e_quality } & -1.3784 & $1 \%$ Level & -3.7880 & $-5.3648^{* * * *}$ & $1 \%$ Level & -3.8085 \\
\hline & $(0.2684)$ & $5 \%$ Level & -3.0123 & $(0.0000)$ & $5 \%$ Level & -3.0206 \\
\hline & & $10 \%$ Level & -2.6461 & & $10 \%$ Level & -2.6504 \\
\hline
\end{tabular}

Table 2

Descriptive Statistics

\begin{tabular}{|c|c|c|c|c|c|}
\hline Variables & Mean & Median & Maximum & Minimum & Std. Dev. \\
\hline t_arrivals & 0.8790 & 0.8800 & 1.3400 & 0.5500 & 0.2326 \\
\hline t_receipts & 6.6950 & 6.6350 & 7.9900 & 5.5400 & 0.8117 \\
\hline r_law & 0.1118 & 0.0200 & 0.5800 & -0.2310 & 0.3065 \\
\hline r_quality & 0.2304 & 0.2150 & 0.4900 & 0.0600 & 0.1269 \\
\hline c_corruption & -0.2959 & -0.3350 & -0.0710 & -0.4901 & 0.1206 \\
\hline p_stability & -0.5345 & -0.8912 & 0.6400 & -1.4412 & 0.7871 \\
\hline v_accountability & -0.2263 & -0.3650 & 0.4700 & -1.0501 & 0.5297 \\
\hline g_effectiveness & 0.2700 & 0.2600 & 0.4500 & 0.0900 & 0.0984 \\
\hline e_quality & 0.5073 & 0.4736 & 0.98743 & 0.39744 & 0.0364 \\
\hline
\end{tabular}

\subsection{Correlation Analysis}

The correlation analysis is used to predict the strength of correlation among all the variables used in the study. Table 3 presents the Pearson Correlation Matrix for all the variables to check the multicollinearity in the data. The highest correlation coefficient $(0.2744)$ is in between political stability and control of corruption. It shows that multicollinearity does not affect the data.

Table 3

Correlation Matrix

\begin{tabular}{|c|c|c|c|c|c|c|c|c|c|}
\hline Variables & 1 & 2 & 3 & 4 & 5 & 6 & 7 & 8 & 9 \\
\hline 1.t_arrivals & 1.0000 & & & & & & & & \\
\hline 2.t_receipts & -0.1256 & 1.0000 & & & & & & & \\
\hline 3. r_law & -0.1682 & 0.21272 & 1.0000 & & & & & & \\
\hline 4. r_quality & -0.0994 & -0.1312 & 0.0113 & 1.0000 & & & & & \\
\hline 5.c_corruption & -0.1954 & 0.1633 & 0.2438 & 0.1873 & 1.0000 & & & & \\
\hline 6. p_stability & -0.2514 & 0.2314 & 0.2710 & -0.0339 & 0.1605 & 1.0000 & & & \\
\hline 7. v_accountability & -0.0242 & 0.2046 & 0.1327 & 0.1373 & 0.3960 & 0.1181 & 1.0000 & & \\
\hline 8. g_effectiveness & 0.2678 & -0.2152 & -0.2867 & 0.3045 & -0.3881 & -0.1784 & -0.1614 & 1.0000 & \\
\hline 9. e_quality & 0.2542 & 0.0345 & 0.2654 & 2.6274 & 0.2663 & 0.0245 & 0.2634 & 0.2744 & 1.0000 \\
\hline
\end{tabular}




\subsection{Regression Analysis}

Table 4 (Panel A) provides the results for the impact of country governance on tourism. The Table shows that there is a positive $(\beta=0.05, p=0.01)$ impact of rule of law on tourism measured by tourism receipts. The impact is significant at $1 \%$ level. If the quality of rule of law increases by $1 \%$ the tourism industry improves by $5 \%$. The results are similar with previous researchers (Steyn \& Vuuren, 2016; Maniatis, 2016; Tsai et al., 2012). Control of corruption shows significant positive $(\beta=$ $0.05, p=0.05)$ impact on tourism receipts. It also has a positive $(\beta=0.05, p=0.04)$ impact on the number of arrivals. The positive coefficient of control of corruption implies that any increase in the value of control of corruption causes an increase in the number of tourists and tourism receipts by 5\%. The previous studies (Gallego et al., 2016; Das \& Dirienzo, 2010; Ekine, 2018) agree with these evidences.

There is significant positive $(\beta=0.09, \mathrm{p}=0.00)$ interaction between political stability and tourism measured by both tourism receipts and number of arrivals. Politically stable economies would increase the tourism receipts as well as number of arrivals by $9 \%$. The results confirm the evidence of previous studies (Ingram et al., 2013; Steyn \& Vuuren, 2016; Tsai et al., 2012). Government effectiveness posits significant positive $(\beta=0.08, \mathrm{p}=0.04)$ impact on tourism receipts. $1 \%$ increase in government effectiveness causes an $8 \%$ increase in tourism receipts by $8 \%$. Similarly, government effectiveness has a significant positive $(\beta=0.04, p=0.00)$ impact on the number of arrivals. It shows that $1 \%$ increase (decrease) in government effectiveness causes an increase (decrease) in the number of arrivals by $4 \%$. The results are similar with the previous researchers (Kubickova, 2016; Fuentes, 2013; Steyn and Vuuren, 2016).

There is an insignificant impact of rule of law on tourism measured by the number of arrivals. There is an insignificant relationship between regulatory quality and tourism measured by both tourism receipts and number of arrivals. The outcomes of regulatory quality are inconsistent with (Steyn and Vuuren, 2016; Maniatis, 2016; Tsai et al., 2012). Voice and accountability also found to be insignificantly associated with tourism which is inconsistent with previous studies (Fuentes, 2013; Steyn and Vuuren, 2016). The hypotheses 2 and 5 are rejected.

Panel B of Table 4 shows that the impact of t_receipts (0.2554) and t arrival (0.1863) is also significant on e_quality. Result indicates that 1 -unit of increase in t_receipts will reduce (increase) $0 . \overline{2} 554$ units of e_quality $\left(\mathrm{CO}_{2}\right.$ emissions), while 1 -unit of increase in $\mathrm{t}$ arrivals will reduce (increase) 0.1863 units of e_quality $\left(\mathrm{CO}_{2}\right.$ emissions). Results are aligned with (Danish \& Wang, 2018; Gupta \& Dutta, 2018; Paramati et al., 2017).

Table 4

Regression Analysis

\begin{tabular}{|c|c|c|c|c|}
\hline \multicolumn{5}{|c|}{ Panel A: Impact of Country Governance on Tourism } \\
\hline \multirow[b]{2}{*}{ Variables } & \multicolumn{2}{|c|}{ Model 1: $t$ _receipts } & \multicolumn{2}{|c|}{ Model 2: $\mathbf{t}$ _arrivals } \\
\hline & Coefficient & p-value & Coefficient & p-value \\
\hline Constant & 6.6899 & $0.0000^{* * *}$ & 0.8882 & $0.0000^{* * *}$ \\
\hline r_law & 0.0491 & $0.0157^{* * * *}$ & 0.0811 & 0.7867 \\
\hline r_quality & -0.0779 & 0.8941 & 0.1722 & 0.5540 \\
\hline c_corruption & 0.0524 & $0.0502^{* *}$ & 0.0489 & $0.0470^{* *}$ \\
\hline p_stability & 0.0980 & $0.0000^{* * *}$ & 0.0898 & $0.0001^{* * *}$ \\
\hline v_accountability & -0.2289 & 0.3587 & 0.0528 & 0.6455 \\
\hline g_effectiveness & 0.0814 & $0.0480^{* *}$ & 0.0404 & $0.0000^{* * *}$ \\
\hline R-Squared & & & & \\
\hline Adj. R-Squared & & & & \\
\hline \multicolumn{5}{|c|}{ Panel B: Impact of Tourism on Environment Quality } \\
\hline & \multicolumn{2}{|c|}{ Model 3: e_quality } & \multicolumn{2}{|c|}{ Model 4: e_quality } \\
\hline Variables & Coefficient & p-value & Coefficient & p-value \\
\hline t_receipts & 0.2554 & $0.0000^{* * * *}$ & --- & -- \\
\hline t_arrivals & -- & -- & 0.1863 & $0.0271^{* *}$ \\
\hline$\overline{\mathbf{R}}$-Squared & \multicolumn{2}{|c|}{0.6894} & \multicolumn{2}{|c|}{0.6473} \\
\hline Adj. R-Squared & \multicolumn{2}{|c|}{0.6657} & \multicolumn{2}{|c|}{0.6147} \\
\hline
\end{tabular}

\section{Discussions and Conclusions}

At the end of the twentieth century, country governance has become the hottest topic in various spheres, government, society at large and academia; numerous insinuations to the subject, both in conversation and writing, nothing has become unusual. The study, therefore, empirically examines the impact of country governance on tourism in Pakistan. The data for the period of 1997 to 2018 are collected from the World Bank and Global Economy. Augmented Dickey Fuller (ADF) test and ordinary least square regression models are used to analyze the impact. Tourism is used as a dependent variable while country governance is used as an independent variable. Six governance indicators developed by Kaufmann et al. (2005) are used to measure country governance. These indicators include rule of law, regulatory quality, control of corruption, political stability, voice and accountability and government effectiveness. 
There is a positive impact of rule of law on tourism. The results are similar with previous researchers (Steyn and Vuuren, 2016; Maniatis, 2016; Tsai et al., 2012). Here, the hypothesis-1 is accepted. The result implies that rule of law principle promotes tourism status in Pakistan. The rule of law principle tends to be seen as a whole along with state welfare principle as well as fundamental rights of the second generation. The rule of law deserves improvements via its ceremonial association with recent legal tools like sustainable development principle and third generation rights. Further fascinating development comprises the modern emergence of different rights of new generation which are passionately interlinked. Thus, tourism implies or at least includes the right to enjoy different facets of cultural and natural environment as a tourist and as a traveler. Obviously, it is of vital importance to devote the right of enjoyment of one's free time including the particular right of tourism. The rule of law should be promoted at a higher level. This tool should include the rule of law in its new version related to the political and individual rights. It should be connected with state welfare principles and should be associated with sustainable development. The study recommends the researchers to promote the research on the relationship between law and tourism. Control of corruption shows significant positive impact on tourism accepting evidence of previous studies (Gallego et al., 2016; Das \& Dirienzo, 2010; Ekine, 2018). One-point increase in the corruption perception index (control of corruption) causes to increase the tourist arrivals by $5 \%$. The result confirms the third hypothesis of the study. Practically, it is impossible to completely control the corruption in Pakistan, but up to some extent it would be true. Generally, it is believed that a reduced or controlled corruption level would stimulate a healthier society. So, the public must be careful in electing choices and struggle to elect a good leader who carefully sustains the tourism culture. Since, there are enough rules to control the corruption; these rules must be implemented in a blanket form. Also, in general, public officers' welfare packages should continually and positively be reviewed.

There is positive interaction between political stability and tourism. The result supports the evidence from previous studies (Ingram et al., 2013; Steyn \& Vuuren, 2016; Tsai et al., 2012). The hypothesis-4 is accepted. Political stability improves security and safety in the democratic nations like Pakistan and has the perspective for tourism to continue to prosper. For an unstable country, the possible tourists may change their destination or cancel their reservations. The tourism industry needs a stable financial, legal and political system in which it can operate. There is a need for government support for the development of the tourism industry. Consequently, tourism destination planners should continuously monitor their country and to work with the government towards stability and protection and safety of tourists and for the general public.

Government effectiveness posits a positive impact on tourism. It implies that a one-unit increase in government effectiveness leads to an increase in tourism by $4 \%$ to $8 \%$. The results are similar with the previous researchers (Kubickova, 2016; Fuentes, 2013; Steyn \& Vuuren, 2016). Here, hypothesis-6 is supported. Government involvement promotes tourism in Pakistan. Providing public goods is of vital importance for tourism which makes an argument for the intervention of the government. Tourism is highly vulnerable to failure and distortion than other sectors and personified by free riders, the government involvement is very important in terms of management of destination, getting involved in planning, promotion, legislation, monitoring, financing and regulating tourism resources (Tang \& Jang, 2009). The actions of the government should be taken into consideration for the development of the tourism industry.

Tourism sector postulates a negative impact on environmental quality. Results are aligned with the prior studies (Danish \& Wang, 2018; Gupta \& Dutta, 2018; Paramati et al., 2017). Here the $7^{\text {th }}$ hypothesis of the study is also accepted. It is concluded that the tourist degraded the environmental quality of Pakistan. It is suggested that the government of Pakistan should promote technological and operational improvement to the vehicle industry so that the motor-vehicles consume less fuel that will ultimately improve the environmental quality.

\section{References}

Beaumont, N., \& Dredge, D. (2010). Local tourism governance: A comparison of three network approaches. Journal of Sustainable Tourism, 18(1), 7-28.

Bramwell, B., \& Lane, B. (2011). Critical research on the governance of tourism and sustainability. Journal of Sustainable Tourism, 19(4-5), 411-421.

Buckley, R. (2012). Sustainable tourism: Research and reality. Annals of tourism research, 39(2), 528-546.

Danish, \& Wang, Z. (2018). Dynamic relationship between tourism, economic growth, and environmental quality. Journal of Sustainable Tourism, 26(11), 1928-1943.

Das, J., \& Dirienzo, C. (2010). Tourism competitiveness and corruption: A cross-country analysis. Tourism economics, 16(3), $477-492$.

Duran, C. (2013). Governance for the tourism sector and its measurement. UNWTO Statistics and TSA. Issue Paper Series, 1-34. https://www.e-unwto.org/doi/pdf/10.18111/9789284415632

Erkuş-Ozturk, H., \& Eraydın, A. (2010). Environmental governance for sustainable tourism development: Collaborative networks and organisation building in the Antalya tourism region. Tourism management, 31(1), 113-124.

Goymen, K. (2000). Tourism and governance in Turkey. Annals of Tourism Research, 27(4), 1025-1048.

Gupta, M. R., \& Dutta, P. B. (2018). Tourism development, environmental pollution and economic growth: A theoretical analysis. The Journal of International Trade \& Economic Development, 27(2), 125-144. 
Hall, C. M., \& O’Sullivan, V. (1996). Tourism, political stability and violence. Tourism, crime and international security issues, 105-121. https:/www.sciencedirect.com/science/article/abs/pii/S0160738397000935

Hall, J. C. (2006). Positive externalities and government involvement in education. Journal of private enterprise, 21(2), 165175.

Hoxha, A. (2010). Causality between prices and wages: VECM analysis for EU-27. Romanian Economic Journal, 13(37), 337.

Ingram, H., Tabari, S., \& Watthanakhomprathip, W. (2013). The impact of political instability on tourism: case of Thailand. Worldwide hospitality and tourism themes, 5(1), 92-103.

Kaufmann, D., Kraay, A., \& Zoido-Lobaton, P., (2005). Governance Matters IV, Governance Indicators for 1996-2004. World Bank Policy Research Department Working Paper, available electronically at www.worldbank.org/wbi/governance/govdata/.

Kubickova, M. (2016). The Role of Government in Tourism: Linking Competitiveness, Freedom, and Developing Economies. Czech Journal of Tourism, 5(2), 73-92.

Lv, Z., \& Xu, T. (2017). A panel data quantile regression analysis of the impact of corruption on tourism. Current Issues in Tourism, 20(6), 603-616.

Maniatis, A. (2016). Tourism and the 'rule of law. African Journal of Hospitality, Tourism and Leisure, 5(1), 1-13.

Michael, E. (2001). Public choice and tourism analysis. Current issues in tourism, 4(2), 308-330.

Munnell, A. H., \& Cook, L. M. (1990). How does public infrastructure affect regional economic performance?. New England economic review, (Sep), 11-33.

Paramati, S. R., Shahbaz, M., \& Alam, M. S. (2017). Does tourism degrade environmental quality? A comparative study of Eastern and Western European Union. Transportation Research Part D: Transport and Environment, 50, 1-13.

Paskaleva-Shapira, K. A. (2007). New paradigms in city tourism management: Redefining destination promotion. Journal of Travel Research, 46(1), 108-114.

Phakdisoth, L., \& Kim, D. (2007). The determinants of inbound tourism in Laos. ASEAN Economic Bulletin, $24(2), 225-237$.

Poprawe, M. (2015). A panel data analysis of the effect of corruption on tourism. Applied Economics, 47(23), $2399-2412$.

Presenza, A., Del Chiappa, G., \& Sheehan, L. (2013). Residents' engagement and local tourism governance in maturing beach destinations. Evidence from an Italian case study. Journal of Destination Marketing \& Management, 2(1), 22-30.

Saha, S., \& Yap, G. (2015). Corruption and tourism: An empirical investigation in a non-linear framework. International Journal of Tourism Research, 17(3), 272-281.

Gallego, S. M., RossellÃ-Nadal, J., \& Fourie, J. (2016). The effects of terrorism, crime and corruption on tourism. Economic Research Southern Africa (ERSA), 595, 1-28. https://aecit.org/files/congress/19/papers/150.pdf

Sonmez, S. F. (1998). Tourism, terrorism, and political instability. Annals of Tourism Research, 25(2), 416-456.

Steyn, R., \& Jansen van Vuuren, O. (2016). The relationship between quality of governance and foreign tourist numbers. African Journal of Hospitality, Tourism and Leisure, 5(4), 1-10

Tang, C., \& Jang, S. (2009). The tourism-economy causality in the United States: A sub-industry level examination. Tourism Management, 30(4), 553-558.

Zapata, M. J., \& Hall, C. M. (2012). Public-private collaboration in the tourism sector: Balancing legitimacy and effectiveness in local tourism partnerships. The Spanish case. Journal of Policy Research in Tourism, Leisure and Events, 4(1), 61-83. 
(C) 2021 by the authors; licensee Growing Science, Canada. This is an open access article distributed under the terms and conditions of the Creative Commons Attribution (CC-BY) license (http://creativecommons.org/licenses/by/4.0/). 